\title{
Influence of anthelmintic baits on the occurrence of causative agents of helminthozoonoses in red foxes (Vulpes vulpes)
}

\author{
D. ANTOLOVÁ, M. MITERPÁKOVÁ, K. REITEROVÁ, P. DUBINSKÝ
}

Parasitological Institute of Slovak Academy of the Sciences, Hlinkova 3, 04001 Košice, Slovak Republic, E-mail: halas@saske.sk

\begin{abstract}
Summary
Red fox (Vulpes vulpes) presents major wildlife reservoir of parasitozoonoses, transmissible to humans and domestic animals. The study was aimed to find out the effect of anthelmintic baits on the occurrence of Echinococcus multilocularis and other intestinal helminths in red foxes. In two bait areas (B1 and B2) 20 baits per $\mathrm{km}^{2}$ were distributed monthly between August 2004 and April 2005. Fox fecal samples were collected in both bait areas and two control areas (C1 and C2) between August 2004 and August 2005. In bait area $\mathrm{B} 1$ the decrease of parasite species number, decrease of their prevalence and prevalence of E. multilocularis was observed. No significant decline was observed in bait area B2, probably due to consumption of baits by wild boars. Bait distribution represents the possibility of reduction of environmental contamination with parasites and their propagation stages. Especially on the periphery of towns and villages and in recreational areas it seems to be suitable way of human health protection.
\end{abstract}

Key words: red fox; bait; praziquantel; fenbendazol; helminthozoonosis; Echinococcus multilocularis

\section{Introduction}

Red fox (Vulpes vulpes) is the most abundant wild carnivore in the territory of the Slovak Republic. After 1996, the significant increase of its population as the result of oral antirabies vaccination has been observed. The number of red foxes increased from 6154 in 1993 to 13331 in 1996 and since 2001, more than 18000 of foxes is shot every year in Slovakia (Statistical Yearbook of the Slovak Republic 1994, 1997, 2002, 2003). Although this animal is primarily predator, it is capable to feed on vegetarian and carnivorous diet and also on human garbage, which aids its survival in areas of urbanisation. Urbanisation of red foxes is phenomenon well known in many cities of Europe and America (Gloor et al., 2001) and has been observed also in
Slovakia (Dubinský et al., 2003).

As a part of biocenosis, fox participates not only in maintaining the cycle of nature, but also in the spreading of several parasitic diseases; many of them being zoonotic and can be transmitted to humans and domestic animals. The most important is alveolar echinococcosis caused by small tapeworm Echinococcus multilocularis, in which life cycle red fox serves as main definitive host. In the Slovak Republic E. multilocularis was for the first time observed in 1999 (Dubinský et al., 1999) and in 2005 and 2006 its prevalence in red foxes reached $37 \%$ (Miterpáková et al., 2006a). Other serious helminthozoonosis that can be spread by foxes is larval toxocarosis, caused by larval stages of Toxocara spp. In Slovakia, Letková et al. (2005) observed $25.8 \%$ prevalence of $T$. canis eggs in red foxes examined coprologically between 2000 and 2004. Many other intestinal helminths of red fox can cause human diseases, for example Capillaria spp., Ancylostoma caninum, Strongyloides spp. and Opistorchis spp.

Field trials have been conducted to reduce the E. multilocularis prevalence in Germany, Japan and Switzerland (Schelling et al., 1997; Tsukada et al., 2002; Hegglin et al., 2003). After using of praziquantel-containing baits authors observed decrease of prevalence of echinococcosis in red foxes.

The aim of this study was to find out the effect of baits containing praziquantel and fenbendazol on the occurrence of E. multilocularis and other intestinal helminths in red foxes living on the periphery of villages and near human settlements, with the biggest human infection risk.

\section{Material and Methods}

Study area

The study was conducted in Prešov region, in which the second highest prevalence of E. multilocularis has been observed in red foxes in the Slovak Republic (Miterpáková 
et al., 2006a). In the area with high population density of red foxes two bait (B1 and B2) and two control localities (C1 and $\mathrm{C} 2$ ) of $2 \mathrm{~km}^{2}$ each were selected. Bait and control areas were situated along the periphery of villages. Control areas were separated from bait ones by at least $10 \mathrm{~km}$ to minimize the chance of foxes using both, bait and control areas. Average altitude of chosen areas ranged between 375 and $439 \mathrm{~m}$ above sea level (a.s.1.) and according to Miterpáková et al. (2003) E. multilocularis is the most prevalent in red foxes living at $200-400 \mathrm{~m}$ a.s.l.

All localities were of similar characteristics. Bait locality B1 was characterised by arable lands, meadows and transitional woodland and shrubs. In this section the presence of high number of small mammals was recorded. Bait locality B2 was defined by permanent grasslands with transitional shrubs and bounded by mixed forest and fields. In B2 locality the high population density of wild boars was observed. It was confirmed by many findings of their presence in mentioned area, and according to gamekeeper a herd of more than 60 animals lived in bait area and its close surroundings. Both control localities were characterised by land areas with high proportion of natural vegetation, fields, and shrubs and in C1 locality the dump site was situated.

\section{Experimental design}

The firm producing commercial baits for antirabies vaccination prepared baits based on fish meat. Instead of antirabies vaccine, one tablet of Bihelminth (Riemser Tierarzneimittel, Germany) containing $50 \mathrm{mg}$ of praziquantel and $500 \mathrm{mg}$ of fenbendazolum was used per bait. Bihelminth tablets are used in the dose 1 tablet per $10 \mathrm{~kg}$ of body weight and the producer declares its efficiency against Toxocara canis, Toxascaris leonina, Ancylostoma caninum, Uncinaria stenocephala, Trichuris vulpis, Echinococcus granulosus, E. multilocularis, Dipylidium caninum, Taenia spp., Taenia multiceps and Mesocestoides spp.

In baited areas 20 baits per $\mathrm{km}^{2}$ were distributed monthly during 9 months between August 2004 and April 2005. Baits were distributed manually at places that were most likely to be often visited by foxes (e.g., near fox dens, were foxes and their tracks had been seen). Baits were handled with rubber gloves to avoid olfactory contamination and were placed under the shrubs or grass to protect them from sun.

In both, baited and non-baited areas fox fecal samples were collected every month between August 2004 and August 2005. To distinguish fox fecal samples from other faeces several criteria, such as size, shape, homogeneity and smell were used (Steiger et al., 2002). Samples were stored at - $70^{\circ} \mathrm{C}$ at least for 7 days to minimise the risk of E. multilocularis infection.

\section{Fecal samples examination}

All fecal samples were investigated for the occurrence of intestinal parasites by the standard flotation method using the Sheather solution (saturated sucrose solution, specific gravity 1.3).
Echinococcus spp. coproantigen in samples was detected using commercial ELISA test kit (CHEKIT® - Echinotest, Dr. Bommeli, Switzerland).

Faeces with positive ELISA results and faeces with negative ELISA results, but with the presence of Taenia spp. eggs were examined by nested PCR (Dinkel et al., $1998)$ to detect E. multilocularis DNA. Shortly, after alkaline hydrolysis of fecal samples (diluted with distilled water) with $1 \mathrm{M} \mathrm{KOH}$ and $1 \mathrm{M}$ dithiothreitol, samples were neutralised with $2 \mathrm{M}$ Tris $\mathrm{HCl}$ and $25 \% \mathrm{HCl}$. Then DNA was extracted with phenol-chloroform-isoamyl alcohol (25:24:1) and $1.8 \mathrm{ml}$ of aqueous phase was transferred into new tube. DNA bound on pellets of matrix after adding a total of $5.4 \mathrm{ml}$ of binding buffer (6 M Sodium acetate) and $30 \mu$ of Prep-A-Gene Matrix (BIO-RAD, France). After centrifugation, the pellet was washed three times. Following drying, the DNA was eluted by resuspending the matrix in $100 \mu \mathrm{l}$ of double-distilled water and incubating for $15 \mathrm{~min}$ at $50^{\circ} \mathrm{C}$. The target sequence for amplification was part of E. multilocularis mitochondrial $12 \mathrm{~S}$ rRNA gene. The PCR was conducted in two steps. For the first PCR, the primer pair P60.for and P375.rev was used. In a second step, the primer pair Pnest.for and Pnest.rev was used for nested PCR. After amplification, $10 \mu \mathrm{l}$ of PCR products was visualised on a $1.5 \%$ agarose gel containing $1 \mu \mathrm{g} . \mathrm{ml}^{-1}$ ethidium bromide.

\section{Statistical analysis}

All prevalences were calculated with $95 \%$ confidence interval. Differences in prevalence rate between bait and control areas were analysed using Fisher exact test. The significance of the differences in percentage of positive fecal samples during monitored period was evaluated by the chi-square test.

\section{Results}

A total of 886 fox faeces were collected through the whole study period. The mean numbers of fecal samples collected every month were $37.3(8-61)$ and $30.7(9-42)$ in the baited and control sections, respectively.

\section{Prevalence of E. multilocularis}

Out of 886 fox faeces examined for the presence of Echinococcus spp. coproantigens, 329 samples were coproantigen positive. These positive samples were examined by nested PCR method to detect E. multilocularis DNA. In 13 samples negative result was recorded, probably due to the inhibition of PCR reaction. In one sample with the finding of Taenia spp. eggs, negative result of coproantigen detection but positive PCR result was recorded. For analysis of bait distribution efficacy, only samples with positive PCR result were considered to be positive.

In August 2004, at the beginning of the trial, the prevalence of E. multilocularis ranged from $33.3 \%$ to $50.0 \%$ in all monitored localities. In bait locality B1, the first decrease of its prevalence was observed after two bait distributions, in October and November 2004 (26.7 \%, and 25.0\%, 


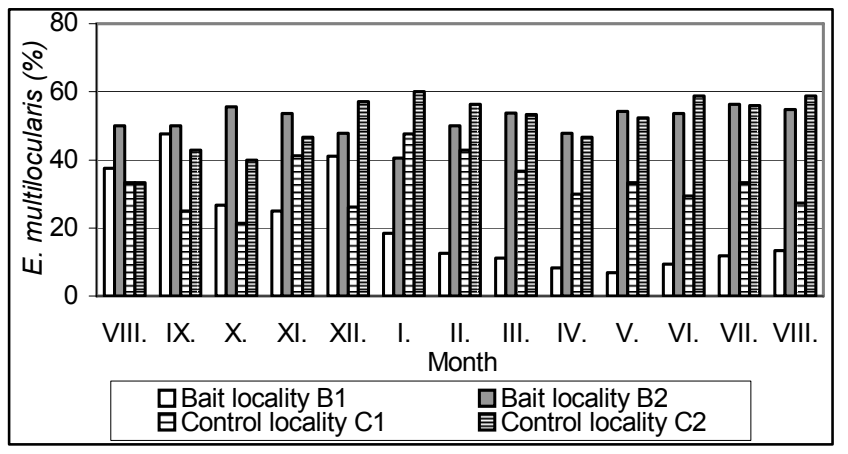

Fig. 1. Percentage of fox fecal samples positive to E. multilocularis during and after baiting period

respectively). Following the increase of E. multilocularis prevalence in December $(41.1 \%)$, repeated decrease with the minimum in May 2005, one month after the last bait distribution, was recorded. Then the infection level remained low, with small elevation observed in last two months of the monitoring. Observed changes of E. multilocularis prevalence were statistically significant $(\mathrm{P}=0.01 ; \mathrm{X}=$ 25.95). In bait locality $B 2$, changes in prevalence of echinococcosis in red foxes were not of significant differences $(\mathrm{P}=1.00 ; \mathrm{X}=0.95)$. Within the whole study period the prevalence ranged from $40.5 \%$ in January 2005 to $56.3 \%$ in July 2005. Similarly, the changes in infection rate recorded in both control localities, $\mathrm{C} 1$ and $\mathrm{C} 2$ were not statistically significant $(\mathrm{P}=0.99 ; \mathrm{X}=3.85$, and $\mathrm{P}=0.99 ; \mathrm{X}=$ 1.39 , respectively). In $\mathrm{C} 1$ locality, prevalence ranged between $21.4 \%$ in October 2004 and $47.9 \%$ in January 2005. In control area $\mathrm{C} 2$, the infection rate fluctuated from 33.3 $\%$ in August 2004 to $60 \%$ in January 2005 (Fig. 1).

\section{Intestinal helminths in red foxes}

In bait area B1 coprological investigation revealed occurrence of 6 helminth species before bait distribution (in August 2004). Their number decreased to 4 species in April 2005 when the baiting was finished. Also the decline of helminth prevalence was observed. In 3 parasite species

Table 1. Occurrence of helminth eggs in $\%$ in fox fecal samples before and after bait distribution in baited areas

\begin{tabular}{|c|c|c|c|c|c|c|}
\hline \multirow[b]{2}{*}{ Helminth species } & \multicolumn{3}{|c|}{ Bait area B1 } & \multicolumn{3}{|c|}{ Bait area B2 } \\
\hline & $\begin{array}{c}\text { August } 2004 \\
\text { (C.I. } 95 \% \text { ) }\end{array}$ & $\begin{array}{l}\text { April 2005 } \\
\text { (C.I. 95\%) }\end{array}$ & $\mathrm{P} *$ & $\begin{array}{l}\text { August } 2004 \\
\text { (C.I. } 95 \% \text { ) }\end{array}$ & $\begin{array}{l}\text { April } 2005 \\
\text { (C.I. 95\%) }\end{array}$ & $\mathrm{P} *$ \\
\hline Taenia spp. & - & - & - & $11.1(1.9-34.1)$ & $4.3(0.0-22.7)$ & 0.34 \\
\hline Dipylidium caninum & $0.0(0.0-13.5)$ & $1.6(0.0-9.6)$ & 0.74 & - & - & - \\
\hline Trichuris vulpis & $23.8(10.2-45.5)$ & $9.8(4.3-20.2)$ & 0.11 & $38.9(20.2-61.5)$ & $26.1(12.3-46.8)$ & 0.21 \\
\hline Capillaria spp. & $28.6(13.6-50.2)$ & $0.0(0.0-5.1)$ & 0.0005 & $5.6(0.0-27.7)$ & $4.3(0.0-22.7)$ & 0.50 \\
\hline Ancylostoma spp. & $4.8(0.0-24.4)$ & $1.6(0.0-9.6)$ & 0.39 & $11.1(1.9-34.1)$ & $8.7(1.3-28.0)$ & 0.38 \\
\hline Uncinaria spp. & $14.3(4.1-35.5)$ & $0.0(0.0-5.1)$ & 0.02 & $5.6(0.0-27.7)$ & $0.0(0.0-12.5)$ & 0.45 \\
\hline Toxocara canis & $9.5(1.5-30.1)$ & $8.2(3.2-18.2)$ & 0.33 & $33.3(16.1-56.4)$ & $13.0(3.7-33.0)$ & 0.14 \\
\hline Toxascaris leonina & $14.3(4.1-35.5)$ & $0.0(0.0-5.1)$ & 0.02 & $38.9(20.2-61.5)$ & $8.7(1.3-28.0)$ & 0.06 \\
\hline Strongyloides spp. & - & - & - & $11.1(1.9-34.1)$ & $0.0(0.0-12.5)$ & 0.21 \\
\hline $\mathrm{n}$ & 21 & 61 & - & 18 & 23 & - \\
\hline
\end{tabular}

* Fisher exact test; $\mathrm{n}$ - number of examined fox fecal samples

Table 2. Occurrence of helminth eggs in \% in fox fecal samples before and after bait distribution in control areas

\begin{tabular}{|c|c|c|c|c|c|c|}
\hline \multirow[b]{2}{*}{ Helminth species } & \multicolumn{3}{|c|}{ Control area $\mathrm{C} 1$} & \multicolumn{3}{|c|}{ Control area $\mathrm{C} 2$} \\
\hline & $\begin{array}{l}\text { August } 2004 \\
\text { (C.I. } 95 \%)\end{array}$ & $\begin{array}{l}\text { April 2005 } \\
\text { (C.I. 95\%) }\end{array}$ & $\mathrm{P}^{*}$ & $\begin{array}{c}\text { August } 2004 \\
\text { (C.I. } 95 \%)\end{array}$ & $\begin{array}{l}\text { April 2005 } \\
\text { (C.I. 95\%) }\end{array}$ & $\mathrm{P} *$ \\
\hline Taenia spp. & $16.7(6.1-36.5)$ & $6.7(0.8-22.4)$ & 0.20 & $0.0(0.0-24.9)$ & $13.3(2.5-39.1)$ & 0.39 \\
\hline Mesocestoides spp. & $8.3(1.2-27.0)$ & $10.0(2.7-26.4)$ & 0.35 & $0.0(0.0-24.9)$ & $13.3(2.5-39.1)$ & 0.39 \\
\hline Trichuris vulpis & $37.5(21.1-57.4)$ & $30.0(16.5-48.0)$ & 0.20 & $10.0(0.0-42.6)$ & $60.0(35.7-80.3)$ & 0.08 \\
\hline Capillaria spp. & $20.8(8.8-40.9)$ & $13.3(4.7-30.3)$ & 0.23 & $10.0(0.0-42.6)$ & $6.7(0.0-31.5)$ & 0.50 \\
\hline Ancylostoma spp. & $4.2(0.0-21.9)$ & $3.3(0.0-18.1)$ & 0.5 & $40.0(16.7-68.8)$ & $6.7(0.0-31.5)$ & 0.11 \\
\hline Uncinaria spp. & $8.3(1.2-27.0)$ & $3.3(0.0-18.1)$ & 0.34 & $10.0(0.0-42.6)$ & $6.7(0.0-31.5)$ & 0.50 \\
\hline Toxocara canis & $20.8(8.8-40.9)$ & $60.0(42.3-75.4)$ & 0.04 & $30.0(10.3-60.8)$ & $46.7(24.8-69.9)$ & 0.27 \\
\hline Toxascaris leonina & $41.7(24.4-61.2)$ & $13.3(4.7-30.3)$ & 0.05 & $30.0(10.3-60.8)$ & $0.0(0.0-18.0)$ & 0.09 \\
\hline Physaloptera spp. & $12.5(3.5-31.8)$ & $3.3(0.0-18.1)$ & 0.21 & $0.0(0.0-24.9)$ & $13.3(2.5-39.1)$ & 0.39 \\
\hline Spirocerca spp. & $0.0(0.0-12.1)$ & $3.3(0.0-18.1)$ & 0.56 & $0.0(0.0-24.9)$ & $6.7(0.0-31.5)$ & 0.62 \\
\hline Strongyloides spp. & - & - & - & $0.0(0.0-24.9)$ & $6.7(0.0-31.5)$ & 0.62 \\
\hline $\mathrm{n}$ & 24 & 30 & - & 10 & 15 & - \\
\hline
\end{tabular}

* Fisher exact test; $\mathrm{n}$ - number of examined fox fecal samples 
(Capillaria spp., Uncinaria spp., T. leonina) this decline was statistically significant. In bait area B2, after baiting the number of parasite species fell from 8 to 6 . Similarly to bait area B1, helminth prevalence fell down, but only in the case of T. leonina this decrease was significant (Tab. 1).

In control area $\mathrm{C} 1$, eggs of 9 and 10 helminth species were detected coprologically before and after bait distribution period, respectively. In some parasites their prevalence decline was observed, but in some species its prevalence increased. In control area $\mathrm{C} 2$, the number of helminth species increased from 6 at the beginning of monitored period to 10 after its end and the changes in parasite prevalence were not statistically significant (Tab. 2).

Figure 2 shows monthly changes in number of fox fecal samples positive to helminths. In bait locality B1 the percentage of samples with occurrence of helminth eggs decreased after 4 months of bait distribution. After small elevation in January 2005, the smallest number of helminth eggs was observed in February 2005. The decline was statistically significant $(\mathrm{P}=0.006 ; \mathrm{X}=34.2)$ and remain obvious till the end of study period, with only small increase observed at the end of monitoring. In bait locality B2, number of faeces positive to helminth eggs fell after one month of bait distribution from $91.6 \%$ to $66.7 \%$, but then remained stable during next 7 months. In last 4 moths the decrease of egg prevalence was observed, but these changes were not significant ( $\mathrm{P}=0.96 ; \mathrm{X}=4.79)$. In both control localities ( $\mathrm{C} 1$ and $\mathrm{C} 2$ ), helminth eggs occurrence fluctuated minimally with changes being not statistically significant, $\mathrm{P}=0.98 ; \mathrm{X}=4.38$ and $\mathrm{P}=0.99 ; \mathrm{X}=2.10$, respectively.

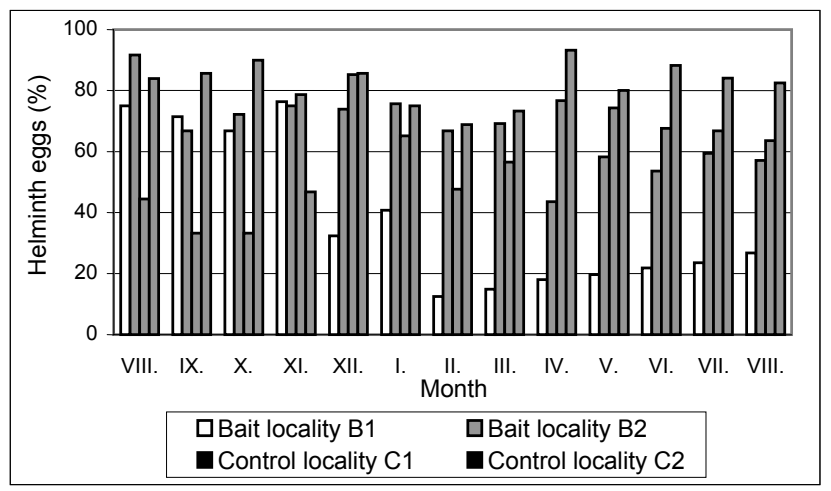

Fig. 2. Percentage of fox fecal samples positive to helminths eggs during and after baiting period

\section{Discussion}

Out of all wild animals living in the territory of Slovak Republic, red fox is harbouring the most varied composition of helminths. Environmental contamination with parasite eggs can cause infection of domestic animals, and thus increase the infection pressure on people. Field studies conducted in big areas showed that anthelmintic baiting is one of the most useful counter measures to control E. multilocularis (Tackmann et al., 2001; Tsukada et al., 2002).

Control of echinococcosis is of great importance in many countries. Determination of E. multilocularis prevalence in red foxes indicates the degree of environmental contamination. Except necropsy that can be used only post mortem and coproantigen diagnosis that is of low sensitivity in the case of low worm burden (Reiterová et al., 2005), nested PCR presents valuable way of E. multilocularis prevalence detection. Low sensitivity of coproantigen ELISA can be the reason of false negative ELISA result of sample with the presence of Taenia spp. eggs and positive PCR result. On the other hand, fecal samples sometimes contain factors, which are yet unidentified and can inhibit PCR reaction (Wilde et al., 1990). Such factors could cause the occurrence of 13 kopro-ELISA positive but PCR negative samples.

In the Slovak Republic six human cases of alveolar echinococcosis have been recorded since 2002. Prešov region, in which the survey was conducted, is region where two of these human cases were diagnosed (Kinčeková et al., 2005) and also where the first finding of naturally infected intermediate host in the Slovak Republic was observed (Miterpáková et al., 2006b). Long-term survey of prevalence of echinococcosis in red foxes (using sedimentation and scraping technique - SCT) have shown $46-48 \%$ overall prevalence of E. multilocularis in monitored area and its surroundings (Miterpáková et al., 2006a). This finding correlates with our observation at the beginning of baiting period. Similarly as in the case of decrease of helminth species number, only in bait area B1 the decline of $E$. multilocularis prevalence was recorded. The changes of its prevalence in other areas were non-significant. This could be caused by the consumption of baits in bait area B2 by another animal species, predominantly wild boars which density was high in this area. In bait locality B1, which was not influenced by bait loses caused by wild boars, the increase of percentage of fecal samples positive to helminths eggs and E. multilocularis prevalence was observed after the end of bait distribution. Several authors recorded similar tendencies (Hegglin et al., 2003; Hansen et al., 2003) that can be due to reinfection of foxes soon after deworming by larval stages of parasites in intermediate or paratenic hosts. In other studies, the decrease of infection rate was observed, but eradication of E. multilocularis was not achieved under the conditions tested (Ito et al., 2003).

Besides E. multilocularis, which zoonotic significance is well known, many other parasites can cause human diseases, one of them being Toxocara spp. Its importance pointed out Havasiová et al. (1993) who recorded 13.7 \% seroprevalence of toxocarosis in healthy blood donors in Slovakia. Circulation of this helmithozoonosis in our territory was confirmed not only by surveys on red foxes (Miterpáková et al., 2005), but also by serological examination of wild boars and small mammals in which $5.1 \%$ and $7.7 \%$ seroprevalence, respectively, was recorded (Antolová et al., 2006). There were several other causative agents of 
helminthozoonoses found within this study. The most common helminth species was T. leonina, which zoonotic potential is considered as being absent or very limited. Nevertheless, at least mucosal penetration of its larval stages was described to occur after ingestion of its eggs by man (Overgaauw \& van Knapen, 2000). Besides mentioned before, out of other helminth species found within this study, Taenia spp., Dipylidium caninum, Capillaria spp., Ancylostoma spp. and Strongyloides spp. can cause human disease as well. In all these parasite species their prevalence decrease was observed after bait distribution in bait locality B1. On the contrary, in bait locality B2 the decline of helminth prevalence was non-significant, probably due to bait loses mentioned before. In both control localities no significant decrease was observed, even the increase of parasite species number was recorded in $\mathrm{C} 2$ locality.

High financial charges present the disadvantage of largescale bait distribution. Therefore bait distribution strategy that focuses on smaller areas may be more realistic and efficient. In endemic areas, characterised by high risk of human infection, anthelmintic baits distributed on the periphery of towns and villages and in recreational localities present the way of human health protection. In this way also stray dogs and cats, other human health risk factors, can be treated.

In conclusion, our study demonstrates the possibility of reduction of environmental contamination with parasite propagational stages, especially in small areas. However, this form of anthelmintic strategy seems to be unsuitable in areas with high population of omnivores, particularly wild boars.

\section{Acknowledgement}

This study was supported by Science and Technology Assistance Agency under the contract No. APVT-51-0107 04 and partially financed by the Slovak Grant Committee VEGA, Grant No. 2/4179/26.

\section{References}

Antolová, D., Reiterová, K., Dubinský P. (2006): The role of wild boars (Sus scrofa) in the circulation of trichinellosis, toxocarosis and ascariosis in the Slovak Republic. Helminthologia, 43: $92-97$

Dinkel, A., Von Nickisch-RosenegK, M., Bilger, B., Merli, M., Lucius, R., Romig, T. (1998): Detection of Echinococcus multilocularis in the definitive host: coprodiagnosis by PCR as an alternative to necropsy. J. Clin. Microbiol., 36: $1871-1876$

DUBINSKÝ, P., SVOBODOVÁ, V., TURČEKOVÁ, L., LITERÁK, I., MARTíneK, K., ReITEROVÁ, K., KolÁŘOVÁ, L., KLIMEŠ, J., MrLíK, V. (1999): Echinococcus multilocularis in Slovak Republic: The first record in red foxes (Vulpes vulpes). Helminthologia, 36: 105 - 110

DubinskÝ, P., Miterpáková, M., HurníkovÁ, Z., ToMAŠOVIČOVÁ, O., REITEROVÁ, K., VÁRADY, M., ŠNÁBEL, V., TurČEKovÁ, L', KÖNigovÁ, A., MachKovÁ, N.
(2003): The role of red foxes in the spread of helminthozoonoses. Slov. vet. čas., 1: $9-32$

Gloor, S., Bontadina, F., Hegglinn, D., Deplazes, P., BREITENMOSER, U. (2001): The rise of urban fox population in Switzerland. Mamm. Biol., 66: $155-164$

HaVAsiovÁ, K., DubinskÝ, P., ŠTEFAnČíKOVÁ, A. (1993): A seroepidemiological study of human Toxocara infection in the Slovak Republic. J. Helminthol., 67: 291 - 296

Hansen, F., Tackmann, K., Jeltsch, F., Wissel, C., THULKe, H.-H. (2003): Controlling Echinococcus multilocularis - ecological implications of field trials. Prev. Vet. Med., 60: $91-105$

Hegglin, D., Ward, P. I., Deplazes, P. (2003): Anthelmintic baiting of foxes against contamination with Echinococcus multilocularis. Emerg. Inf. Dis., 9: 1266 - 1272

Ito, A., Romig, T., TAKAHASHI, K. (2003): Perspective on control options for Echinococcus multilocularis with particular reference to Japan. Parasitology, 127: 159 - 172

KINČEKOVÁ, J., DUBINSKÝ, P., DVOROŽŇÁKOVÁ, E., AUER, H., HudačKová, J., DaŇová, M., Stanislayová, M., StraKA, L., SzILÁGYOVÁ, M. (2005): Diagnostics and occurrence of alveolar echinococcosis in the Slovak Republic. Slov. česká gastroenterol., 59: $11-16$

Letková, V., Lazar, P., Čurlík, J., GoldovÁ, M., KoČIŠOVÁ, A. (2005): Actual diseases of the game on the territory of the Slovak Republic. Programme and abstracts of IV. International Symposium on Wild Fauna, 4. - 9. 9. 2005, Tatranská Lomnica: 67 - 71

MiterpákOVÁ, M., DubinskÝ, P., REITEROVÁ, K., MACHKOVÁ, N., VÁRADY, M., ŚNÁBEL, V. (2003): Spatial and temporal analysis of the Echinococcus multilocularis occurrence in the Slovak Republic. Helminthologia, 40: 217 $-226$

MiterpákovÁ, M., AntolovÁ, D., VÁrAdy, M., DubinSKÝ, P. (2005): Parasitofauna of red foxes in the Slovak Republic. Slov. vet. čas., 3: $168-170$

MiterpákovÁ, M., DubinskÝ, P., StAnko, M. (2006a): Long-term survey of Echinococcus multilocularis extension in the territory of Slovakia with the stress on climatic and environmental factors. VII. Slovak and Czech Parasitological Days, 23. - 27.5.2006, Modra-Harmonia: 28 MiterPÁKOVÁ, M., ANTOlOVÁ, D., ŠEVČíKOVÁ, Z., STANKO, M., DINKEL, A., GAŠPAR, V., DUBINSKÝ, P. (2006b): Echinococcus multilocularis in musk rat (Ondatra zibethicus): the first finding of the parasite in naturally infected rodent in the Slovak Republic. Helminthologia, 43: 76-80 OvergaAuW, P. A. M., VAN KNAPEN, F. (2000): Toxocarosis. In MACPHERSON, C. N. L., MusLin, F. X., WANDELer, A. I. (Eds.): Dogs, Zoonoses and Public Health. Oxon, CABI Publishing: $213-222$

ReITEROVÁ, K., MiterPÁKovÁ, M., TURČEKOVÁ, L., ANTOLOVÁ D., DUBINSKÝ, P. (2005): Field evaluation of an intravital diagnostic test of Echinococcus multilocularis infection in red foxes. Vet. Parasitol., 128: $65-71$

Schelling, U., Frank, W., Will, R., RoMig, T., LuCiUs, R. (1997): Chemotherapy with praziquantel has the potential to reduce the prevalence of Echinococcus multilocularis in wild foxes (Vulpes vulpes). Ann. Trop. Med. Pa- 
rasitol., 91: $179-186$

Statistical Yearbook of the SlovaK Republic 1993. VEDA, BratislavA, 1994

Statistical YearboOK OF the SlovaK Republic 1996. VEDA, Bratislava, 1997

Statistical YearboOK of the SlovaK Republic 2001. VEDA, Bratislava, 2002

StATISTICAL YeARbOOK OF THE SLOVAK RePUbliC 2002. VEDA, Bratislava, 2003

Steiger, C., Hegglin, D., Schwarzenbach, G., Mathis, A., DePlazES, P. (2002): Spatial and temporal aspects of urban transmission of Echinococcus multilocularis. Parasitology, 124: $631-640$

Tackmann, K., LÖSchner, U., Mix, H., StaubaCh, C., ThulKe, H. - H., Ziller, M., Conraths, F. V. J. (2001):
A field study to control Echinococcus multilocularis-infections of the red fox (Vulpes vulpes) in an endemic focus. Epidemiol. Inf., 127: 577 - 587

TSUKADA, H., HAMAZAKI, K., GANZORIG, S., IwAKI, T., KonNO, K., LAGAPA, J.T., MATSUO, K., ONO, A., SHIMIZU, M., SaKai, H., Morishima, Y., NonaKa, N., OKU, Y., KAMIYA, M. (2002): Potential remedy against Echinococcus multilocularis in wild red foxes using baits with anthelmintic distributed around fox breeding dens in Hokkaido, Japan. Parasitology, 125: 119 - 129

Wilde, J., EIDEN, J., YolKEN, R. (1990): Removal of inhibitory substances from human fecal specimens for detection of a group A rotaviruses by reverse transcriptase and polymerase chain reaction. J. Clin. Microbiol., 28: $1300-$ 1307 